Oxygen is an essential element to conduct life processes but some of the metabolic byproducts e.g. reactive oxygen species (ROS), are toxic for living organisms. Endogenous ROS are produced e.g. reduction of dioxygen; some exogenous sources of radicals also exist, including nicotine and ionizing radiation. Reactive oxygen species include superoxide anion, hydroxyl radical, singlet oxygen, hydrogen peroxide and hypochlorous acid.

Carcinogenesis is a multistep process. The exact reasons for the development of cancer are still unknown. Many factors contribute to the development of carcinogenesis, one of which is oxidative stress. Oxidative stress is defined as an imbalance between oxidizing agents (pro-oxidants) and antioxidants, agents that protect biomolecules against injury by pro-oxidants. When reactive oxygen species are overproduced it can damage nucleic acids, proteins and lipids. ROS are considered as a significant class of carcinogens participating in cancer initiation, promotion and progression.

Key words: oxidative stress, reactive oxygen species, reactive nitrogen species, oxidative damage, cancer, carcinogenesis.

\section{Oxidative damage and carcinogenesis}

\author{
Joanna Katarzyna Strzelczyk, Andrzej Wiczkowski
}

Chair and Department of General Biology, Medical University of Silesia, Zabrze, Poland

Oxygen is an essential element to conduct life processes, but its high chemical reactivity is a reason why some of its metabolic by products are toxic for living organisms. These include reactive oxygen species (ROS) and free radicals $[1,2]$. Free radicals are atoms or molecules that can exist independently, yet they have one or more unpaired electrons [3]. Free radicals strive to have their electrons paired, that is to get rid of a surplus electron or to bind another one. Therefore they are highly reactive [4]. Reactive oxygen species (ROS) include superoxide anion $\left(\bullet^{\circ} \mathrm{O}_{2}^{-}\right)$, hydroxyl radical $\left({ }^{\bullet} \mathrm{OH}\right)$, singlet oxygen $\left({ }^{1} \mathrm{O}_{2}\right)$, hydrogen peroxide $\left(\mathrm{H}_{2} \mathrm{O}_{2}\right)$ and hypochlorous acid $(\mathrm{HOCl})$. Reactive oxygen species are produced in endogenous reactions, e.g. in reduction of dioxygen but also under the influence of exogenous sources such as cigarette smoke or ionizing radiation [3, 5-9]. Reactive oxygen species are molecules commonly encountered in living organisms, where they participate in numerous physiological processes. They are mediators in many important functions of organic cells, such as regular growth, differentiation, proliferation and apoptosis [10]. They also play an important role as intra- and extracellular conductors and are the response of cells to tissue hypoxia [2, 3, 7, 9, 11-14].

Oxidative stress is defined as lack of equilibrium between oxidizing substances (pro-oxidants) and antioxidants, that is compounds that protect biomolecules against harmful effects of pro-oxidants [6]. If the volume of created ROS exceeds the organism's ability to recycle them, damage occurs to nucleic acids, proteins and lipids which, in turn, results in dysfunction of cells, tissues or organs of the body [2, 15-21].

It was proven that intense oxidative stress contributes to the pathomechanism of numerous diseases, including senile cataract, atherosclerosis, diabetes and neurodegenerative disease [22-27]. Excessive synthesis of reactive oxygen species and insufficiency of antioxidant defence mechanisms are also contributing aetiological factors of neoplastic diseases [2, 6, 9, 28-37].

Apart from ROS, cell oxidants also include reactive nitrogen species (RNS), such as nitric oxide radical $\left(\mathrm{NO}^{\bullet}\right)$ and peroxynitrite ion $\left(\mathrm{ONOO}^{-}\right)$, also associated with carcinogenesis [7, 13, 38-44].

It is said that RNS are factors that take part in initiation, promotion and progression of carcinogenesis [6, 8, 20, 45-48]. As early as in 1984, Zimmerman and Cerutti [49] proved that exposure of mouse fibroblasts to reactive species of oxygen can lead to carcinogenic transformation of cells. Increased levels of oxidative damage may be a result of: (I) increased production of ROS without further disruption of the antioxidant system, (II) a stable level of ROS with simultaneously a less effective antioxidant system, (III) errors in the system that repairs oxidative damage in the DNA, or (IV) a combination of the above $[6,13,44,50]$.

The conducted research proves that excessive production of ROS and related oxidative stress are features characteristic for neoplastic cells, both in vivo and in vitro $[15,16,50-57]$. Moreover, the results of the research of Kondo et al. [50] showed increased levels of ROS in cases of adenocarcinoma when compared to cases of colorectal cancer. The main causes of increased levels of ROS in neoplastic cells, when compared to the normal tissue surrounding them, is excessive production of ROS related to the 'respiratory (oxidative) burst' of phagocytes, as well as an increasing volume of ROS in the part of the cir- 
culatory system which surrounds the neoplastic changes [15, 45]. Moreover, increased metabolic activity of neoplastic cells also intensifies production of superoxide anion radical [58].

Reactive oxygen species are considered to be a pro-neoplastic factor as they stimulate proliferation, invasiveness, angiogenesis and metastasis, and inhibit apoptosis [44, 59, 60]. They are able to stimulate development of a neoplasm in the promotion stage through influencing genes related to apoptosis and proliferation. As a result of 'an attack' of free radicals, the concentration of $\mathrm{Ca}^{2+}$ ions increases within the intracellular area, which results in activation of proto-oncogenes such as c-fos, c-jun, c-myc or activated protein kinase C (PKC). That, in turn, intensifies proliferation and speeds up the carcinogenesis [2, 6, 61]. High concentrations of ROS and their derivatives influence activation of transcription factors including NF-אB, which results in induction of cytokine gene expression and of growth factors. That leads to intensified proliferation of cells and occurrence of neoplastic lesions in otherwise healthy tissue [6, 14, 44, 62]. Reactive oxygen species also influence activity of proteins involved in the cell cycle, such as p53 protein [14]. If there is no oxidative stress or after a period of mild stress, p53 activity is related to the antioxidant response of the cell through activation of transcription of MnSOD and GPX1 coding genes [63]. High levels of production of reactive oxygen species may also cause increased activity of p53 protein. However, excessive levels of ROS may inhibit p53 activity, which is related to the inhibition of apoptosis [44, 64]. Moreover, a relationship between ROS and invasiveness or occurrence of metastasis was also proven [65-67]. Oberley et al. [68] observed that human cells that originated from metastatic changes in the course of prostate cancer produced more ROS than the original cancer cells. Moreover, the influence of ROS on the development of angiogenesis through an increase in production of vascular endothelial growth factor (VEGF) was also proven $[66,69]$.

Numerous research studies indicate participation of ROS, which act within cells, as secondary relays in the intracellular signal cascade. They induce and sustain the oncogenic phenotype of neoplastic cells. Moreover, there is an increasing amount of evidence that ROS can induce aging of cells and their apoptosis or necrosis, as well as being able to inhibit the process of angiogenesis, therefore being antineoplastic molecules [2, 6, 44, 70].

The biggest participation in the process of carcinogenesis, especially in the initiation phase, is attributed to the hydroxyl radical $[13,20]$. The hydroxyl radical can react with both the deoxyribose molecule and nitrogenous bases which are elements of the DNA. A reaction between the hydroxyl radical and the deoxyribose molecule produces both single and double cracks of the DNA strands [13, 45, 46]. The results of reactions with nitrogenous bases are their adducts. One of the most typical DNA adducts which is an oxidative product of damage done to nucleic acids is 8-hydroxy-2'deoxyguanosine (8-OHdG) [36, 50, 71-74]. Presence of modified bases can trigger mutational changes which, in turn, may cause inactivation of suppressor genes or activation of proto-oncogenes [6, 8, 13, 45, 75]. The increased levels of 8-OHdG and other modified bases in the DNA are also influenced by possible defects in enzymes that repair oxidative damage in the DNA, which in turn is related to the progression of age-related, increasing incidence of neoplasms [76-78]. Mice without MTH1 enzyme, which hydrolyzes $80 \mathrm{HdGTP}$, suffered from an increasing incidence of lung, stomach and liver cancer with the progress of age $[76,77]$

The superoxide anion radical can inhibit the functions of the mitochondrion through inactivation of the Fe-S centre in the electron transport chain. The ongoing accumulation of damage and inhibition of the mitochondrial activity eventually leads to apoptosis of the cell [2]. It is also assumed that $\mathrm{H}_{2} \mathrm{O}_{2}$ plays some role in the process of carcinogenesis. Hydrogen peroxide is not a radical itself but can be easily transformed into one as a result of Fenton's reaction, in which iron and copper ions $\left(\mathrm{Fe}^{2+}, \mathrm{Cu}^{2+}\right)$ participate [45]. Occurrence of $\mathrm{H}_{2} \mathrm{O}_{2}$ in higher concentrations was also observed in human tumour cells $[13,51]$.

The effects of the influence of ROS include not only damage done to the genetic material but also damage of the cell membrane caused most frequently by free radical oxidation reactions of lipid structures. One of the end products of lipid peroxidation is malondialdehyde (MDA), which can have a mutagenic and carcinogenic influence on a cell $[2,30]$.

Another negative consequence of the presence of ROS is changes in the spatial structure of proteins resulting in the occurrence of new cross-sectional bonds. Moreover, they may cause aggregation and fragmentation of proteins. Additionally, modifications caused by ROS change proteolytic susceptibility and antigenicity of proteins. Denaturation of some proteins was also observed as ROS can oxidize and, subsequently, break thiol groups and disulfide bridges. Reactive oxygen species may cause inactivation of proteolytic inhibitors, which increases activity of proteolytic enzymes against proteins. What is more, ROS react with proteins and lipids, raising the risk of DNA damage $[2,12,42,44]$.

A similar relationship can also be found between other reactive molecules, such as reactive nitrogen species. These oxidants may appear as a result of inducible nitric oxide synthase (iNOS). The nitric oxide radical $\left(\mathrm{NO}^{\bullet}\right.$ ) can react with ${ }^{\bullet} \mathrm{O}_{2}{ }^{-}$ and create ${ }^{\bullet} \mathrm{OH}$ and the peroxynitrite anion $\left(\mathrm{ONOO}^{-}\right)$, which influences the process of lipid peroxidation causing cracks in the DNA and induces transversion-type mutations. They can also disrupt the respiratory chain in the mitochondrion and influence the phosphorylation process of proteins, including p53 type $[6,8,13,14,34,39,79]$. Moreover, reactive nitrogen species cause inhibition in the activity of caspases, which is related to delays in apoptosis. Additionally, inhibition of cytochrome oxidase slows down formation of mitochondrial ATP, impairing the course of proliferation, which in turn may delay the growth of a tumour $[44,80]$.

Cells of eukaryote organisms have created defence mechanisms that limit the level of RNS and damage caused by their actions. Such defence mechanisms include antioxidant enzymes such as superoxide dismutase, glutathione peroxidase, glutathione S-transferase and catalase. These enzymes have various isoforms and occur in both intra- and extracellular areas. Their activity forms an integrated antioxidant protection system $[2,6,7]$. As previously mentioned, an increased level of oxidative damage in tumour cells may also be a result of a less efficient antioxidant system. An example of such inefficiency of the antioxidant protection system as a factor which contributes to carcinogenesis can be the 
case of mice with turned off CuZnSOD gene, which demonstrated an increased incidence of liver tumour progressing with age [81]. Similarly, heterozygous mice that had 50\% of content of the regular mitochondrial MnSOD demonstrated an increased incidence of neoplasms such as leukaemia, adenocarcinomas and pituitary adenomas [82]. Chu et al. [83] carried out a study in which they turned off two out of four GPx genes of mice (that is GPx1 and GPx2). This caused the occurrence of colorectal cancer. Moreover, the mice with decreased activity of catalase proved to be more prone to occurrence of breast tumours [84].

Numerous epidemiological research cases prove that an increase in expression of MnSOD in a group of patients with neoplasms correlates with higher invasiveness and aggressiveness of stomach, intestinal, lung and breast cancers $[67,85]$. Liu et al. [60] proved that MnSOD inhibits the process of apoptosis in the neoplastic cells of the large intestine. They also demonstrated that a selenium deficiency leads to decreased activity of peroxidases and increased risk of the occurrence of neoplastic lesions [86].

Trosko and Upham [87] suggest that oxidative stress not only causes damage of the DNA but also influences epigenetic modification of gene expression that, in turn, is one of the factors of carcinogenesis. Therefore, the influence that epigenetically modified gene expression has on disturbances in proliferation, differentiation and apoptosis of the cell is more and more often emphasized.

\section{References}

1. Abele D. Toxic oxygen: the radical life-giver. Nature 2002; 420: 27.

2. Valko M, Leibfritz D, Moncol J, Cronin MTD, Mazur M, Telser J. Free radicals and antioxidants in normal physiological functions and human disease. Int J Biochem Cell Biol 2007; 39: 44-84.

3. Halliwell B, Gutteridge J. Free radicals in biology and medicine. 3nd ed. Oxford University Press; New York 1999.

4. Bartosz G. Druga twarz tlenu. Wolne rodniki w przyrodzie. Wydawnictwo Naukowe PWN; Warszawa 2003; 19-30.

5. Dreher D, Junod AF. Role of oxygen free radicals in cancer development. Eur J Cancer 1996; 32: 30-8.

6. Klaunig JE, Kamendulis LM. The role of oxidative stress in carcinogenesis. Annu Rev Pharmacol Toxicol 2004; 44: 239-267.

7. Zasadowski A, Wysocki A, Barski D, Spodniewska A. Some aspects of reactive oxygen species (ROS) and antioxidative system agent's action. Short review. Acta Toxicol 2004; 12: 5-19.

8. Ho JC, Mak JC, Ho SP, Ip MS, Tsang KW, Lam WK, Chan-Yeung M. Manganese superoxide dismutase and catalase genetic polymorphisms, activity levels, and lung cancer risk in Chinese in Hong Kong. J Thorac Oncol 2006; 1: 648-53.

9. Lu F. Reactive oxygen species in cancer, too much or too little? Med Hypotheses 2007; 69: 1293-8.

10. Gałecka E, Mrowicka M, Malinowska K, Gałecki P. Wolne rodniki tlenu i azotu w fizjologii. Pol Merkuriusz Lek 2008; 24: 446-48.

11. O'Brian CA, Chu F. Post-translational disulfide modifications in cell signaling-role of inter-protein, intra-protein, S-glutathionyl, and S-cysteaminyl disulfide modifications in signal transmission. Free Radic Res 2005; 39: 471-80.

12. Stańczyk M, Gromadzińska J, Wasowicz W. Roles of reactive oxygen species and selected antioxidants in regulation of cellular metabolism. Int J Occup Med Environ Health 2005; 18: 15-26.

13. Karihtala P, Soini Y. Reactive oxygen species and antioxidant mechanisms in human tissues and their relation to malignancies. APMIS 2007; 115: 81-103.

14. Mates JM, Segura JA, Alonso FJ, Marquez J. Intracellular redox status and oxidative stress: implications for cell proliferation, apoptosis, and carcinogenesis. Arch Toxicol 2008; 82: 273-99.
15. Toyokuni S, Okamoto K, Yodoi J, Hiai H. Persistent oxidative stresS in cancer. FEBS Lett 1995; 358: 1-3.

16. Toyokuni S. Oxidative stress and cancer: the role of redox regulation. Biotherapy 1998; 11: 147-54.

17. Kong Q, Beel JA, Lillehei KO. A treshold concept for cancer therapy. Med Hypotheses 2000; 55: 29-35.

18. Smith TA. Mammalian hexokinases and their abnormal expression in cancer. Br J Biomed Sci 2000; 57: 170-8.

19. Waszczykowska E, Sysa-Jędrzejowska A, Choczaj-Kukuła A. Reactive oxygen species in cell physiology and pathology-therapeutic possibilities. Centr Eur J Immunol 1999; 24: 3-8.

20. Evans MD, Dizdaroglu M, Cooke MS. Oxidative DNA damage and disease: induction, repair and significance. Mutat Res 2004; 567: 1-61.

21. Tanaka M, Chock PB, Stadtman ER. Oxidized messenger RNA induces translation errors. Proc Natl Acad Sci USA 2007; 104: 66-71.

22. Craghill J, Cronshaw AD, Harding JJ. The identification of a reaction site of glutathione mixed-disulphide formation on $\gamma \mathrm{S}$-crystallin in human lens. Biochem J 2004; 379: 595-600.

23. Dalle-Donne I, Rossi R, Giustarini D, Colombo R, Milzani A. Is there a role for $\mathrm{S}$-glutathionylation of proteins in human disease? IUBMB Life 2005; 57: 189-92.

24. Violi F. Cangemi R. Antioxidants and cardiovascular disease. Curr Opin Investig Drugs 2005; 6: 895-900.

25. Ceriello A. Effects of macronutrient excess and composition on oxidative stress: relevance to diabetes and cardiovascular disease. Curr Atheroscler Rep 2006; 8: 472-6.

26. Singh RP, Sharad S, Kapur S. Free radicals and oxidative stress in neurodegenerative diseases: relevance of dietary antioxidants. JIACM 2004; 5: 218-225.

27. Lin MT, Beal MF. Mitochondial dysfunction and oxidative stress in neurodegenerative diseases. Nature 2006; 443: 787-95.

28. Kim GJ, Chandrasekaran K, Morgan WF. Mitochondrial dysfunction, persistently elevated levels of reactive oxygen species and radiationinduced genomic instability: a review. Mutagenesis 2006; 21: 361-7.

29. Cerutti PA. Oxy-radicals and cancer. Lancet 1994; 344: 862- 863.

30. Ray G, Batra S, Shukla NK, Deo S, Raina V, Ashok S, Husain SA. Lipid peroxidation, free radical production and antioxidant status in breast cancer. Breast Cancer Res Treat 2000; 59: 163-70.

31. Bartsch H, Nair J, Owen RW. Exocyclic DNA as oxidative stress markers in colon carcinogenesis: potential role of lipid peroxidation, dietary fat and antioxidants. Biol Chem 2002; 383: 915-21.

32. Gackowski D, Speina E, Zielinska M, Kowalewski J, Rozalski R, Siomek A, Paciorek T, Tudek B, Olinski R. Products of oxidative DNA damage and repair as possible biomarker of susceptibility to lung cancer. Cancer Res 2003; 63: 4899-902.

33. Liu X, Zhao J, Zheng R. DNA damage of tumor-associated lymphocytes and total antioxidant capacity in cancerous patients. Mutat Res 2003; 539: 1-8.

34. Bancel B, Esteve J, Souquet JC, Toyokuni S, Ohshima H, Pignatelli B. Differences in oxidative stress dependence between gastric adenocarcinoma subtypes. World I Gastroenterol 2006; 12: 1005-12.

35. Gonenc A, Erten D, Aslan S, Akinci M, Simsek B, Torun M. Lipid peroxidation and antioxidant status in blood and tissue of malignant breast tumor and benign breast disease. Cell Biol Int 2006; 30: 376-80.

36. Tuzgen S, Hanimoglu H, Tanriverdi T. Relationship between DNA damage and total antioxidant capacity in patients with glioblastoma multiforme. Clin Oncol 2007; 19: 177-181.

37. Yossepowitch O, Pinchuk I, Gur U, Neumann A, Lichtenberg D, Baniel J. Advanced but not localized prostate cancer is associated with increased oxidative stress. J Urol 2007; 178: 1238-44.

38. Thomsen LL, Sargent JM, Williamson CJ, Elgie AW. Nitric oxide synthase activity in fresh cells from ovarian tumour tissue: relationship of enzyme activity with clinical parameters of patients with ovarian cancer. Biochem Pharmacol 1998; 56: 1365-70.

39. Hussain SP, Harris CC. Molecular epidemiology and carcinogenesis: endogenous and exogenous carcinogens. Mutat Res 2000; 462: 311-22.

40. Klatt P, Lamas S. Regulation of protein function by S-glutathiolation in response to oxidative and nitrosative stress. Eur J Biochem 2000; 267: 4928-44.

41. Hofseth LJ, Hussain SP, Wogan GN, Harris CC. Nitric oxide in cancer and chemoprevention. Free Radic Biol Med 2003; 34: 955-68. 
42. Dalle-Donne I, Rossi R, Colombo R, Giustarini D, Milzani A. Biomarkers of oxidative damage in human disease. Clin Chem 2006; 52: 601-23.

43. Beevi SS, Rasheed MH, Geetha A. Evidence of oxidative and nitrosative stress in patients with cervical squamous cell carcinoma. Clin Chim Acta 2007; 375: 119-23.

44. Halliwell B. Oxidative stress and cancer: have we moved forward? Biochem J 2007; 401: 1-11.

45. Ray G, Husain SA. Oxidants, antioxidants and carcinogenesis. Indian J Exp Biol 2002; 40: 1213-32.

46. Klaunig JE, Xu Y, Isenberg JS, Bachowski S, Kolaja KL, Jiang J, Stevenson DE, Walborg EF Jr. The role of oxidative stress in chemical carcinogenesis. Environ Health Perspect 1998; 106: 289-95.

47. Pervaiz S. Pro-oxidant milieu blunts scissors: insight into tumor progression, drug resistance, and novel druggable targets. Curr Pharm Des 2006; 12: 4469-77.

48. Laviano A, Meguid MM, Preziosa I, Fanelli FR. Oxidative stress and wasting in cancer. Curr Opin Clin Nutr Metab Care 2007; 10: 449-56.

49. Zimmerman R, Cerutti P. Active oxygen acts as a promoter of transformation in mouse embryo C3H/10T1/2/C18 fibroblast. Proc Natl Acad Sci USA 1984; 81: 2085-7.

50. Kondo S, Toyokuni S, Iwasa Y, Tanaka T, Onodera H, Hiai H, Imamura M. Persistent oxidative stress in human colorectal carcinoma, but not in adenoma. Free Radic Biol Med 1999; 27: 401-10.

51. Szatrowski TP, Nathan CF. Production of large amounts of hydrogen peroxide by human tumor cells. Cancer Res 1991; 51: 794-8.

52. Brown NS, Bicknell R. Hypoxia and oxidative stress in breast can cer. Oxidative stress: its effects on the growth, metastatic potentia and response to therapy of breast cancer. Breast Cancer Res 2001; 3: 323-7.

53. Zhou Y, Hileman EO, Plunkett W, Keating MJ, Huang P. Free radical stress in chronic lymphocytic leukemia cells and its role in cellular sensitivity to ROS-generating anticancer agents. Blood 2003; 101 4098-104.

54. Hileman EO, Liu J, Albitar M, Keating MJ, Huang P. Intrinsic oxidative stress in cancer cells: a biochemical basis for therapeutic selectivity. Cancer Chemother Pharmacol 2004; 53: 209-19.

55. Lambeth JD. NOX enzymes and the biology of reactive oxygen. Nat Rev Immunol 2004; 4: 181-9.

56. Pelicano H, Carney D, Huang P. ROS stress in cancer cells and therapeutic implications. Drug Resist Updat 2004; 7: 97-110.

57. Okada F, Kobayashi M, Tanaka H, et al. The role of nicotinamide adenine dinucleotide phosphate oxidase-derived reactive oxygen species in the acquisition of metastatic ability of tumor cells. Am J Pathol 2006; 169: 294-302.

58. Spitz DR, Sim JE, Ridnour LA, Galoforo SS, Lee YJ. Glucose depriva tion-induced oxidative stress in human tumor cells. A fundamental defect in metabolism? Ann N Y Acad Sci 2000; 899: 349-62.

59. Malins DC, Polissar NL, Gunselman SJ. Progression of human breast cancers to the metastatic state is linked to hydroxyl radical induced DNA damage. Proc Natl Acad Sci USA 1996; 93: 2557-63.

60. Liu Y, Borchert GL, Donald SP. MnSOD inhibits proline oxidase-induced apoptosis in colorectal cancer cells. Carcinogenesis 2005; 26: 1335-42

61. Hwang TS, Choi HK, Han HS. Differential expression of managanese superoxide dismutase, copper/zinc superoxide dismutase, and catalase in gastric adenocarcinoma and normal gastric mucosa. Eur J Surg Oncol 2007; 33: 474-9.

62. Pikarsky E, Porat RM, Stein I, et al. NF- $\kappa \beta$ functions as a tumour promoter in inflammation-associated cancer. Nature 2004; 431: 461-6.

63. Bensaad K, Vousden KH. Savior and slayer: the two faces of p53. Nat Med 2005; 11: 1278-9.

64. Park SY, Chang I, Kim JY. Resistance of mitochondrial DNA-deplet ed cells against cell death. Role of mitochondrial superoxide dis mutase. J Biol Chem 2004; 279: 7512-20.

65. Mori K, Shibanuma M, Nose K. Invasive potential induced under longterm oxidative stress in mammary epithelial cells. Cancer Res 2004 64: 7464-72.

66. Storz P. Reactive oxygen species in tumor progression. Front Biosc 2005; 10: 1881-96.

67. Connor KM, Hempel N, Nelson KK. Manganese superoxide dismutase enhances the invasive and migratory activity of tumor cells. Can cer Res 2007; 67: 10260-7.
68. Oberley TD. Oxidative damage and cancer. Am J Pathol 2002; 160: 403-8.

69. Huang SS, Zheng RL. Biphasic regulation of angiogenesis by reactive oxygen species. Pharmazie 2006; 61: 223-229.

70. Chandra J, Samali A, Orrenius S. Triggering and modulation of apoptosis by oxidative stress. Free Radic Biol Med 2000; 29: 323-33.

71. Dincer Y, Himmetoglu S, Akcay T, Ersoy EY, Gunes KN, Tortum O. Prognostic significances of oxidative DNA damage evaluated by 8-hydroksydeoxyguanosine and antioxidant enzymes in patients undergoing resection of gastric and colon carcinoma. Neoplasma 2007; 54: 131-6.

72. Foksiński M, Kotzbach R, Szymański W, Oliński R. The level of typicalbiomarker of oxidative stress 8-hydroxy-2-deoxyguanosine is higher in uterine myomas than in control tissue and correlates with the size of the tumor. Free Radic Biol Med 2000; 29: 597-601.

73. Marnett LJ. Oxyradicals and DNA damage. Carcinogenesis 2000; 21: 361-70.

74. Cooke MS, Evans MD, Dizdaroglu M, Lunec J. Oxidative DNA damage: mechanisms, mutation, and disease. FASEB J 2003; 17: 1195-214.

75. Kinnula VL, Crapo JD. Superoxide dismutase in malignant cells and human tumors. Free Radic Biol Med 2004; 36: 718-44.

76. Nakabeppu Y, Tsuchimoto D, Furuichi M, Sakumi K. The defense mechanisms in mammalian cells against oxidative damage in nucleic acids and their involvement in the suppression of mutagenesis and cell death. Free Radic Res 2004; 38: 423-29.

77. Nakabeppu Y, Sakumi K, Sakamoto K, Tsuchimoto D, Tsuzuki T, Nakatsu Y. Mutagenesis and carcinogenesis caused by the oxidation of nucleic acids. Biol Chem 2006; 387: 373-9.

78. Russo MT, De Luca G, Degan P, Bignami M. Different DNA repair strategies to combat the threat from 8-oxoguanine. Mutat Res 2007; 614: 69-76.

79. Carr A, McCall, MR, Frei B. Oxidation of LDL by myeloperoxidase and reactive nitrogen species-reaction pathways and antioxidant protection. Arterioscler Thromb Vasc Biol 2000; 20: 1716-23.

80. Wiseman H, Halliwell B. Damage to DNA by reactive oxygen and nitrogen species: role in inflammatory disease and progression to cancer. Biochem J 1996; 313: 17-29.

81. Elchuri S, Oberley TD, Oi W, Eisenstein RS, Jackson Roberts L, Van Remmen H, Epstein CJ, Huang TT. CuZnSOD deficiency leads to persistent and widespread oxidative damage and hepatocarcinogenesis later in life. Oncogene 2005; 24: 367-80.

82. Van Remmen H, Ikeno Y, Hamilton M, et al. Life-long reduction in MnSOD activity results in increased DNA damage and higher incidence of cancer but does not accelerate aging. Physiol Genomics 2003; 16: 29-37.

83. Chu FF, Esworthy RS, Chu PG, Longmate JA, Huycke MM, Wilczynski S, Doroshow JH. Bacteria-induced intestinal cancer in mice with disrupted Gpx1 and Gpx2 genes. Cancer Res 2004; 64: 962-8.

84. Ishii K, Zhen LX, Wang DH, Funamori Y, Ogawa K, Taketa K. Prevention of mammary tumorigenesis in acatalasemic mice by vitamin $\mathrm{E}$ supplementation. Jpn J Cancer Res 1996; 87: 680-4.

85. Toh Y, Kuninaka S, Oshiro T, et al. Overexpression manganase superoxide dismutase mRNA may correlate with aggressiveness in gastric and colorectal adenocarcinomas. Int J Oncol 2000; 17: 107-12.

86. Lei XG, Cheng WH, McClung JP. Metabolic regulation and function of glutathione peroxidase-1. Annu Rev Nutr 2007; 27: 41-61.

87. Trosko JE, Upham BL. The emperor wears no clothes in the field of carcinogen risk assessment: ignored concepts in cancer risk assessment. Mutagenesis 2005; 20: 81-92.

\section{Address for correspondence}

\section{Joanna Katarzyna Strzelczyk}

Chair and Department of General Biology

Medical University of Silesia

Jordana 19

41-808 Zabrze, Poland

Submitted: $\quad 27.01 .2010$

Accepted: $\quad 9.08 .2011$ 